\title{
UNDERSTANDING THE REASONS FOR TRANSITION FROM IRANIAN CONSTITUTIONAL STATE TO AUTHORITARIAN STATE: AN ANALYSIS IN THE FRAMEWORK OF LACLAU AND MOUFFE'S DISCOURSE THEORY
}

\section{INRODUCTION}

One of the most important revolutionary movements of modernity is the constitutional revolution began in 1906, during the reign of the Qājār dynasty in Iran. The foundation of the constitutional state is the first experience of the modern state in Iran. The lasting result of this political event has been the change in power relations and the restriction of authoritarian power (Rowshanfekr, 2018). In Iran however, the formation of a modern state has been as a result of the establishment of state institutions for more than a century. Since Abbās Mirzā, many reformers have emerged in Iran's political atmosphere, often belonging to the bureaucratic class of society and have made serious attempts to establish modern institutions and to bring new order. Although such efforts in Iran have suffered many setbacks and failures, they have played a central role in the process of forming a modern state. Founded on the basis of two key elements such as "Constitution" and "parliament;" constitutional revolution took place in order to change dictatorship government to constitutional state. In addition to breaking the structure of the old autocracy over Iran, it paved the way to carry out the socio-political manifestations of modernity (including consultative assembly, the constitution, parties, political groups, press, etc.). Consequently, "in the Constitutional period, it can see the emergence of political, social and intellectual parties and groups in Iran, influenced by modernity that overtly entered for the first time into the field of power and competed with each other" (Rahbari, 2009: 106-108).

Under Constitutional law in Iran however, the sovereignty was entrusted to a disunited and dispersed nation surrounded by the sovereignty of the tribal reformulations and the unity of the widespread political and administrative domains. Therefore, in the peripheral regions "power centres have become more autonomous and chaotic, and subsequently national unity and integration have been seriously weakened after the Constitution and the new born state has failed to build the nation and national unity" 
(Rowshanfekr, 2018: 440). The Constitutional political discourse was born in response to the political and social upheavals of Iranian society. At first sight it seemed that the constitutional discourse succeeded in constituting and marking the dispersed and separate elements and forces of court's discourse and colonialism, and acquired social importance from the standpoint of social approach. In this research, the authors seek to answer the following question: Why the Constitutional movement was unable to consolidate its discourse signs after hegemony and could never impose its semantic order that finally paved the way to its decadence. The authors put forward this hypothesis that the constitutional discourse and movement seem to have evolved under the influence of political and social contexts such as the conflict of micro-discourse in society, the intervention of foreign forces, and the autonomy of centrifugal forces like the rebellion of tribal forces. The main problematic here is to show and investigate constitutional revolution incapability to form a cohesive discourse through national solidarity and unity that led to collapse in the absence of economic efficiency, the weakness of central state and stable security resulting in the cycle of despotism and chaos after the constitutional state. Research methodology is descriptive-analytical conducted by library-based data.

\section{LITERATURE REVIEW}

Since its emergence in 1906, Constitutional discourse has been one of the most powerful discourses in Iranian society. Various sectors of society, such as bureaucrats, workers, students, petty traders and some villagers were organized around this discourse. Constitutionalists' official propaganda, organizations and agencies increasingly played a role in Iran's socio-political development. The clerics, the intellectuals, the political, the cultural and economic elites were in constant conflicts with political and government officials after the years of Iran-Russia wars. The constitutional discourse reacted to the Russian-English cultural, political and social movements in Iran, then tried to stabilize otherness with the discourse of the courts and foreign forces (Ahmadi, 2011).

Generally, the constitution was a mirror to reflect the ideals and ideas of intellectuals on national sovereignty, freedom and equality. The ideas of territorial and economic reform, cultural secularism, ancient nationalism and anti-clericalism later implemented in the Pahlavi dynasty had roots in constitutionalists' thought. It is worth mentioning that "the intellectual movement is one of the politico-social pillars in contemporary Iranian history that tried to replace its goals and ideals" (Husseini, 1994: 2-3). Establishing a regime based on secular law was the utopia of Mirzā Malkam Khān ${ }^{1}$ to difficulties of Iran (Haeri, 2001).

On the government, politics, economy and religion, and in order to reform and improve the situation of Iranians, he tried to eradicate superstitions and illusions and

${ }^{1}$ (1834-1908) prominent Iranian modernist, preoccupied with the transformation of Iran into a modern state. Armenian state figure, diplomat, enlightener, writer and publicist in Iran. Mirza Malkam Khān is well-known as social reformer and enlightener. He is the first Christian who has adopted the title of "MIRZA" in Persia. 
tried to reconcile modern human achievements, rationality and science on the one hand and religious teachings and practices and traditional customs on the other hand. In this way, he pursued to tie the idea of religious renaissance to Islamic nations by modeling it from the Western thoughts and to inform people and scholars that civilization, modernity, science and education are essential to life and are not in sharp contrast with Islamic Protestantism as proposed by him (Adamiyat, 2008). Facing West, Reformers who had trouble finding the reasons for Iran's decline and retardation came to the conclusion that the problems of nomadic communities as one of the main causes of Iran's retardation are the historical vestige and a legacy left by the Turks and Mongols (Cronin, 1997).

In general, for the nationalist and reformist, and for the majority of urban society and the intellectual elite, one of the main issues of any favorable and defensible government was its will and capacity to dismantle this historic fortune. Progress, development, order, political stability, national independence and unity have been all the requirements of the abandon of nomadic life style. During the constitutional era, most political parties and groups followed this policy and belief. Sayyed Hassan Taghizādeh, ${ }^{2}$ one of the opponents of Rezā Khan, admired his action to repress the nomadic communities and tribes and supported Rezā Khān's candidature in Parliament insisting on his assiduity establish security (Maki, 2001).

After the hegemonization of constitutional discourse in Iran, the forces and factors influencing the process of nation-building, the formation and survival of an independent state or country can be studied according two different models: the first model is based upon exogenous and endogenous factors; and the second relies on the superstructure and the underlying factors. In the first model, factors such as colonization, external threats and the regional and global powers that accompany them are exogenous and shared history, territorial unity, common culture, religion, language, ethnicity, race and nationalism are the endogenous challenges. In the second model, factors such as situation, territorial unity, common culture, history, language, religion, ethnicity and race are the fundamental issues on the one hand and nationalism, political structure of space, external threats, colonialism, political ideology, national symbols, the power of central state, the communicative structure, the competition of powers, etc. on the other hand have the infrastructural function (Hāfez Niā, 2002).

The multiplicity of neighbors, at the same time, provides a good basis for increasing rate of discord among neighboring states. Territorial and border conflicts, conflicts over shared oil resources and water right of border rivers, functional issues of border and ideological clashes among neighboring states often find their meaning in this way. In fact, there is a direct relationship between the number of neighbors and the increase in demand. Such a situation evokes the flow of life and security in overcrowded neighborhoods. The situation becomes worse when the neighbors of a country are also abundant and less developed. In this case, poor neighbors are a constant and uncontrollable source of all kinds of crises and tensions. In this situation, even if the palace or palaces are built, they will not be immune to the sources of tensions. All these factors

2 (1878-1970), an influential Iranian politician and diplomat of Azeri origin during the Qājār dynasty under the reign of Mohammad Ali Shah, as well as the Pahlavi dynasty under the reign of Rezā Shāh and Mohammad Rezā Shāh. 
have created sources of conflict between the Iranian government and its neighbors. These sources fall into three groups: sources of geo-economic conflicts, sources of geopolitical and geostrategic conflicts and sources of geo-cultural conflicts (Karimi Pour, 2000).

Geopolitical sources of contentions are formed when independence, territorial integrity, national unity and security and the fundamental values of the nation state are linked to the geographic space and politics of other nations. Indeed, geopolitical and geostrategic problems arise where the foreign policy of nations or their military strategy is under the influence of the geographic state especially the relative position. The constant conflict between Iran's neighbors and the state is due to the long-standing rivalry or interference of cultural interests and resources. The ethnic and nationalistic rivalries, the efforts to export cultural values, the expansion of the axiological system and the support from allies in neighboring countries are among these activities (Karimi Pour, 1992).

Therefore, these destabilizing conditions go to considerable expenses and focus much of state's expenses and forces on controlling insecurity, and offer little or no opportunity to expand and advance the nation-building process and democracy. The geographical position of Iran in South-West Asia, which on the one hand was a link between the eastern and western governments and on the other hand the distance between the Tsardom of Russia and the Persian Gulf, played a crucial role in the political, economic and cultural history of Iran. By taking into account the rich history of Iran dating back to 2500 years, it can conclude that the source of all wars, and other political dilemmas of Iran has been its geographic location which due to its strategic situation has been subjected to the attacks of neighbor and trans-regional countries (Mir Heidar, 2011). It should be noted that the emergence of new civilization in Iranian life as well as the development of commercial affairs are also due to the geographic location of the country. In sum most researchers of the field have already focused on the following factors to the transition from constitutional state to authoritarian state in Iran: a) new born states around Iran, b) underdevelopment of neighboring countries, c) density of ideological states, d) the presence of Trans-regional powers (Karimi Pour, 2001; Karimi Pour, 2000; Gellner, 1983).

\section{THEORETICAL FRAMEWORK}

Laclau and Mouffe's model of discourse analysis is one of the mainstreams of discourse theories within the context of politics. In this approach, Discourses are composed of significant inter-related signs. In Laclau and Mouffe's model of discourse and by taking the advantage of Saussurean linguistics terms, discourse is considered a set of configured and inter-related signs (Torfing, 1999). From this viewpoint, discourse theory consists of a set of interdependent words and signs which form a significant whole. In line with Saussurean theory of language that establishes a link between the arbitrary and the conventional nature of linguistic sign without any inherent relationship between the two, in this approach both sign and concept are floating notion that various discourses try to assign a kind of meaning to them (Husseini Zādeh, 2007; Andersen, 2003). 
Laclau and Mouffe emphasize the role of discourse as an attempt to form a web of meanings within a particular domain. The constitution of a discourse involves the structuring of signifiers into certain meanings to the exclusion of other meanings, and can be seen, therefore as an exercise of power (Howarth, Stavrakakis, 2000). Thus: "Any discourse is constituted as an attempt to dominate the field of discursivity, to arrest the flow of differences, to construct a center" (Laclau, Mouffe, [1985] 2001: 112). In what follows, the authors briefly introduce and discuss the fundamental concepts of discourse analysis as proposed by Laclau and Mouffe.

\section{Hegemony}

To describe hegemony, Gramsci (1971) sometimes designates it as a kind of moral, cultural and intellectual leadership, which can form a coherent political force. Following Gramsci (Ibid.) and his concept of hegemony, Laclau and Mouffe (1985) postulate that hegemony transforms power into reality and establishes domination instead of the force of thought and persuasion; it also gives priority to the ideological apparatus over the coercive apparatus and seeks to obtain popular consent by legitimating hegemonic system. Hegemony is a kind of political logic that leads to common sense and consensus. The significant factor to describe the discourse is its general and metaphorical characteristics. Other discourses emphasize minor demands, but the dominant discourse deviates from reality and takes on a metaphorical dimension. In a general interpretation of the crisis, dominant discourse presents itself as the only determining and reactive framework for all the varied demands and specific aspects. It tries to organize society in its own way and presents a new order.

\section{Configuration}

Any action which communicates between the discrete elements is defined as configuration in such a way that the meaning and the identity of these elements are modified as a result of the above action (Tājik, 2008; Mouffe, 2008).

\section{Moments}

They are signs and elements already configured in discourse that temporarily get their meaning and identity. These meanings and identities are not fully stabilized, it is possible to change them through new configurations (Tājik, 2008).

\section{Elements}

Elements are signs and symbols that are not meant to be configured and that different discourses are trying to make sense of them (Torfing, 1999). 


\section{Central signifier}

A sign around which the other signs are arranged and temporarily find their meaning (Ibid.).

\section{The chain of articulation-equivalence/difference}

In the process of configuration; central signifiers are combined regarding the chain of equivalence. These signs are empty of meaning, which means that they are themselves meaningless. Through the chain of equivalence, they combine with other signs that give them a specific meaning. Then, they encounter with other negative identities that seem threatening to them. The discourses cover all the differences and give them coherence across the chain of equivalence. In the equivalence relation, the elements lose their different characters and meaning and finally the discourse attributes them a meaning (Husseini Zādeh, 2007; Chouliaraki, Fairclough, 1999).

\section{Antagonism}

In Laclau and Mouffe's theory of discourse, identity is always discursive and consequently unstabilized (Clarke et al., 2009). Antagonism forms identity. Naturally, identity is formed in reaction to another. Therefore, antagonisms are not objective relationships, but they mark boundaries. At this stage, the leaders of discourse try to provide a new and attractive interpretation of reality and ideal society (Tājik, 2008).

\section{Otherness}

It is impossible to understand the theory of discourse without understanding the concepts of "antithesis" and "otherness." Discourses are formed essentially in contest with each other. Identifying a discourse is just possible through the structure of other discourses. At this point, the dominant discourse moves away from the metaphorical and generalist atmosphere, and tends to respond to the demands and interests of a part of society, and this is where new hostilities and dislocations arise. Otherness and hostility spread. Under the conditions of establishment; many divisions and forces that have formed a discourse become competitors (Kasraei, Pouzesh Shirazi, 2009).

\section{Dislocation}

According to Laclau and Mouffe (1985[2005]), the notion of dislocation refers to crisis and events challenged by discourse. Because of their hostility and dependence on the concept of "other,, this concept calls into question the fundamental and underlying fragility of discourses. Identities and discourses are always subject to a non- 
intrusive influence. Dislocation is the result of the growing hostility and emergence of plurality and hostility in society, and a sign of the decline of the dominant discourse of hegemony and its inability to interpret reality and absorb social elements. In such circumstances, dislocation surrounds society and tends to disrupt existing order and discourse and leads society to crisis, paving the way to the despair of people and the dispersed social forces surrounding this discourse and the emergence of powerful rivals (Husseini Zādeh, 2007).

\section{ANALYSIS: TRANSITION FROM CONSTITUTIONAL STATE TO AUTHORITARIAN STATE IN IRAN}

\section{Lack of democratic tradition, culture and instability of states}

A careful examination of the governments in power in Iran shows that the political systems in power has been frequently authoritarian or absolutist. Iranian leaders came from all origins and sources, but there was no difference in the rule of individual and authoritarian will. "Iranian history shows that the leaders, whatever their origins, ultimately turned to individual will and individual power and authoritarian absolutism and refused to share power with others" (Sha'bani, 2006, 181-185). In such a system, the monarchy relied on the power of the king, ultimately leading to despotism, and the authority of the king largely consisted of the ownership of all land, the confiscation of property, the monopoly of privileges and benefits and ownership of people's lives and property. The king's will be the law. People were considered the king's slaves, and the king treated them in every possible way (Kasra'i, 2000).

The king had no stable judiciary system and army, and since there was no law in the country, there was no policy in the strict sense. Overall, despite its strength and weakness, the Iranian government had two basic characteristics: first, it had absolute power so that no other entity outside of government could exist. Second, the institution of government has been sanctified (Zibāklam, 1998). In contrast, from the time of Islam to the Pahlavi dynasty, all of the major dynasties that ruled Iran were tribal in nature. When the central government was weak or decentralized, the tribes of Iran opened the way to autonomy and centrism. Thus, "tribal life and its political culture prevailed over Iran. The laws and ways of life of these tribes influenced the vision of the Iranian people, which made it difficult to understand the social and political context of Iranians" (Fiyouzat, 1996: 30).

Despite the anticipation of constitutional structures in the Constitution, the political, social and pro-constitutional elites lacked the capacity to establish and institutionalize the constitutional pillars. The Political instability, the influence of colonial powers, the inability to form political allies and the extreme weakness of the central state have been the result of this inability. During the period of August 1906 - the creation of the Constitutional Assembly in Iran - until the formation of 1921 Persian coup d'état, ${ }^{3}$

${ }^{3}$ Persian coup d'état, refers to several major events in Persia in 1921, which eventually led to the establishment of the Pahlavi dynasty as the ruling house of the country in 1925. 
fifty-one cabinets were reshuffled. On the one hand, the mass of people and the political elite ignoring the concept and reality of the constitution were the major concerns for the intellectuals and on the other hand, they worried about the catastrophic situation of the country and the danger of the collapse of the nation.

They were convinced that a powerful but dependent - reformist government capable of creating and securing national unity and working for its achievement would replace the constitutional state. After this period, national unity became a discourse between intellectuals and political elites (Rowshanfekr, 2018). At the end of the 1st World War, a group of Iranian constitutional activists, intellectuals and millions of people gathered in Berlin. Nationalism, modernism and the desire for progress, as well as frustration with the constitutional movement were their common concern. The group's description of Iranian society signified their desire for a new discourse: hopes for the constitution were dashed and political chaos took place. The country was under foreigner's occupation. Social classes had old fashioned faces, and only certain social actors seem to be newcomers to think of themselves. The people were poor. Public literacy was widespread. The majority of the Iranian population were tribal and rural, and there was no real knowledge of the West. Iranians believed that Westerners are infidels who constantly think about conspiracy against Iran and its occupation. Women' situation was unpleasant. All the opportunists ranging from bourgeois, European, clerics, nouveaux-riches and conservatives were present at the political scene of the country (Behnām, 2000).

The absence of a democratic tradition coupled with cultural weaknesses, the presence of tribes and their centrifugal powers in line with the intervention of foreign powers put the intense pressure on the state that by the end of World War I constitutional movement lost its authenticity. The country was on the brink of national disintegration and the monarchy has not achieved its objectives. Most people and revolutionaries wanted to abandon the first in favor of the second, in other words, the modernization of the administrative and legislative system.

\section{Nomadic communities' uprising}

Nomadic communities were the main obstacles to the formation of national sovereignty and integrity and the failure of the constitutional state in Iran. Such an obstacle remained until the formation of the centralized and modern Pahlavi dynasty. The main reason for the survival of traditional state was the tribal nature of central government. Tensions between the central state and the tribes became apparent when the Pahlavi government was established as a state with no nomadic identity.

The idea of fighting with the tribe and depriving the tribal society of power emerged among intellectuals' elites in the constitutional period. Under Rezā Shah's reign however, treating tribes and nomads as one of the centers of peripheral power was not a sudden and improvised action. The nationalists did not arrive at a common and clear consensus on the tribes and nomads and considered them the symbol of chaos, sufferance and death for people and an obstacle to the unity of the country to solve financial crises and the process of modernization. For this reason, Reza Shāh's policy of no- 
mads' sedentarism and systematization has been more attractive to nationalists than any other policy (Cottam, 1992).

Centrifugal movements such as the revolt of Abolqāsem Lahūtīi ${ }^{4}$ in Azerbaijan and the movement of Mohammad Taghi Khān Pessian ${ }^{5}$ in Khorāsan and the autonomous tribal and nomadic areas were major obstacles to national unity in Iran. For this reason, their existence was unbearable for the authoritarian bureaucratic state. The authoritarian state was determined to expand its power in two directions namely the army and bureaucracy throughout the country. To this end, all the obstacles had to be removed. The confrontation of Pahlavi state with Boyer Ahmadi tribes, Kurds, Qashqāeis is important in this case. At the beginning of the 1921 Persian coup d'état, most of Iran's geographic areas were under the domination of tribes, Khāns, and powerful landowners. Fars province was dominated by the Qashqāei and Khāmseh tribes. The BoyerAhmadi and Mamasani tribes were dominating northern Fārs province and parts of Khuzestān. Khaz'al bin Jabir bin Merdaw al-Ka'bi, known as Sheikh Khazal, ${ }^{6}$ was the uncontested ruler of Khuzestan province and the beaches of the Persian Gulf were dominated by the Dashtestāni and Tangsiri Khāns. Lorestān province itself was made up of several Lor tribes living in a completely autonomous situation on the border with Iraq. Sardar Mākoei in northwestern Azerbaijan, Sardār Mo'azez Bojnourdi in Khorasan, Kurds of Khorāsān in northeastern Iran, Amir Shaukat al-Molk, the ruler of Ghaināt and Sistān in the southeast Iran. Ismaeil Aqā Shakāk ruled all parts of Western Urmia up to the Turkish border who received aid from Turkish nationalists, and his uprising was nationalist and pan-Kurdish in nature (Cronin, 1997). In Khorāsan, there were different tribes such as the Hazāras, the Timurids and the Kurds, and most parts of southeastern Iran were under the rule of the Baloch rulers, Bahrām Khān and Doust Mohammad Khān that the latter minted coins as a sign of declaration of sovereignty (Rowshanfekr, 2018).

Such a situation has convinced the people and some clerics and a large number of intellectuals that the only way to progress and create national security and unity is to dismantle the power of the tribes and form an authoritarian Pahlavi government. Invasion of sedentary and rural areas during migration was among the insecurities caused by the nomads. Pahlavi state aimed at modernizing people's life style which was in its turn another factor to sedentarism of nomadic tribes. One of the main goals of authoritarian bureaucratic state was to modernize Iranian society and nomadic-traditional life style has been an obstacle to this end. This process could potentially provide security and reinforce the project of modernization. Autonomous and nomadic regions and their powerful Khāns were the pseudo states hindering the penetration and influence of central state to another regions of the country. In this case, it should be aware of this fact that the necessity to install a strong national state is to put an end to the Khāns'

\footnotetext{
${ }^{4}$ An Iranian Kurd-Soviet poet and political activist who was active in Iran during the Persian Constitutional Revolution and in Tājikistan in the early Soviet era (1887-1957).

${ }^{5}$ Colonel Mohammad Taqi-Khān Pessiān (1892-1921) was an Iranian gendarme and pilot who formed and lead the short-lived Autonomous Government of Khorāsan. He was killed in a battle with forces sent by Ahmad Qavām, the prime minister at the time.

${ }^{6} \mathrm{He}$ was the Ruler of Arabistān, the Sheikh of Mohammerah from the Kasebite clan of the Banu Ka'b, of which he was the Sheikh of Sheikhs, the Overlord of the Mehaisan tribal confederation and the Ruler of the Shatt al-Arab.
} 
power. The Khāns' could never comply with central state and had their own procedures for government to nominate or depose the headmen (Rowshanfekr, 2018).

The nature of the constitutional state and the emphasis on expanding democratic institutions in the absence of a political culture commensurate with democracy and further weakened the state. The crisis in the influence of the constitutional state and its inability to bring about national unity and integration in surrounding regions was largely due to its democratic nature. Among the attributes of national unity in modern governments are the disappearance of tribal identities, prejudices and the creation of a unified identity based on national elements. Such transformation is the result of the nation-building function of the modern state. Modern constitutional state had no such function in Iran, and not only could penetrate peripheral areas (tribes), but also tribes and clans gained more independence in post-constitutional period in Iran. The growing chaos and insecurity within the constitutional state had created such a situation that the general public and even the leaders and elites of society and, above all, the constitutional rulers were so disillusioned with such a state. At the time, "to the people's eyes the word 'constitutional' was equivalent to word for murder and pillage" (Rasoulzādeh, 1998: 185).

In such a situation and due to the inability of the constitutional state to provide security, the idea of good or bad despotism came into mind of many intellectuals and former supporters of constitutionalism and they believed that it is better to have a kind of despotism (Ibid., 189). The chaos and insecurity in the country have led the country's political elites to reduce some of the constitutional values to achieve the most important ones. In order to achieve centrality, security and authoritarianism, they were convinced that it must relinquish freedom and democracy as the important features of the constitution.

\section{The evolution of Iran's political and military role in 20th century}

In the early 20th century, Iran's foreign policy was based on balance between Britain and Russia's influence within the political and economic spheres. In 1901, the Iranian state granted the privilege of extracting and refining southern oil reserves to an Australian-British called William Knox Darcy. This privilege created a balance between Russian and British influence so that they could formulate Iran's foreign policy as they considered. For instance, during the constitutional movement in Iran, the British state was the tenant of the liberation movement and the Russians were in favor of maintaining an authoritarian regime. In 1905, constitutionalists, with the help of the British government, forced Mozaffar ad-Din Shāh to sign the constitutional decree, and thus the democratic constitutional state replaced the previous authoritarian state in Iran (Browne, 1918). In 1905 and 1907, as Iran was embroiled in its own internal troubles and revolutions, a significant change suddenly emerged in the policy of the British and Russian states due to the emergence of a powerful states like Germany. In other words, with the emergence of a common enemy that was rapidly expanding its territory, these states ended their old hostilities and enmities and entered a treaty of friendship against the common enemy. 
This policy change was to the detriment of Iran, and during the famous AngloRussian Convention of 1907, the Russian and British states, while ensuring the preservation of the territorial integrity and political independence of Iran, divided Iran into two spheres of influence and a neutral zone. The British state and its allies have promised that they would never abuse the commercial or political privileges in the region dominated by Russia. However, at the time, Iranian state officials were not aware of the existence of such a division even after the signing the agreement. Subsequent protests left unanswered, and the so-called agreement formalized the interference of foreign states in Iran's internal affairs. In 1908, for example, the Russian state clearly supported the despotism of Mohammad Ali Shāh and overthrew Iran's new constitutional state. With the dissolution of the National Assembly in 1908, the fires of civil wars were kindled across Iran. First, the uprisings started in Tabriz, then were expanded to Rasht and other cities. At that time, the Russian state cracked down on the freedom fighters by occupying Tabriz and Rasht, but this action of Russians sparked a sense of pride and nationality in other cities of Iran, and the Bakhtiāri tribes immediately formed a national army with the help of Armenians, Caucasians and a number of local inhabitants. After much effort, and finally in 1909, they succeeded in conquering Tehran and re-establishing a constitutional state (Nāzem, 1954). The second major Russian state intervention, which inhibited Iran's economic development and consequently Iran's political development failure, took place in 1911, when the Iranian constitutional state invited an American expert named William Shuster to arrange Iran's finances and resolve Iran's financial and economic crisis. Given Iran's political situation, Shuster's first goal was to form a national army to restore order and collect taxes. To this end, Schuster entrusted the training of the gendarmerie to a British officer.

At the time, the formation of an independent army being independent of the influence of foreign states was impossible since it would strengthen the central government of Iran and was against the interests of foreign powers. Therefore, the Russian ambassador in Tehran called for Shuster's removal from the Iranian state within 48 hours. The British minister of foreign affairs launched a speech in the House of Commons that according to the 1907 Treaty, the British state should prevent a British operation in the region dominated by Russians, to say in northern Iran and Tehran. Under the pressures of the Russians, Shuster was obliged to leave Iran and once again the constitutional state failed to pursue its goals and aspirations, and the modernization process was severely damaged.

Therefore, in 1914, Russia and Britain decided to prevent the expansion of German influence in the Caucasus on the one hand and in the Persian Gulf on the other hand. Therefore, they attacked Iran from the north and the south. During World War II, Allied forces ignored Iran's neutrality and occupied Iran on August 25, 1941 (Mir Heidar, 2011). This event had devastating effects on Iran's internal affairs. Inflation and the cost of living were direct consequences of the Allied presence in Iran. Transport was available to the Allies: there were many currency problems and government exports were cut off, and internal riots and the formation of separatist movements in Azerbaijan and Kurdistan were a direct result of Russian military occupation. Under such circumstances, political development and nation-building efforts in Iran encountered 
with diverse barriers. Iran's strategic position close to Russia forced the Allies to make such a decision, namely the military occupation of Iran. During World Wars I and II, Iran's geographic location and its geostrategic role was the main reason for the forces and the powers involved to violate Iran's neutrality.

During World War II, the occupation of Iran played an important role to shift the balance of power in favor of the Allies and their victory, and Iran has been called the "Bridge of Victory." From the time of the constitutional state until the end of the 2nd Pahlavi, imbalanced and heterogeneous national composition, imbalances in minority participation, inadequate communication systems, geographic and spatial injustices were the other fixed and variable forces influencing national divergence and the major obstacles for national development and social solidarity.

\section{Crisis expansion and unrest in society}

At this point all the forces and signifiers of the dominant discourse (constitutional state) began to dissolute, and remained unable to explain and interpret reality and failed to organize the social world and led to the emergence of powerful rivals. It is worth mentioning to note that various national, regional and international factors paved the way for 1921 Persian coup d'état and the eventual formation of an authoritarian bureaucratic state. By taking into account the internal factors, the constitutional state encountered with several crises that the most important among them was the weakness of the central state and subsequently the existence of local and tribal autonomy. Apart from the devastation caused by World War I and the severe economic and social crises and insecurity in the country, the situation of constitutional state even for the leaders of the Constitutional revolution were frustrating. According to Tabari (1978) the search for Iran's savior had become a common slogan among various segments of the population. Their hopes for the national rulers and the effectiveness of the constitutional system had turned to despair, and they sought the easiest remedy for the pain in the emergence of Naderi (Nāder Shāh) (Ibid.).

Although Russian Revolution (1917) prevented the complete destruction of Iranian independence, but due to the absence of the central state and the power void in the region, it paved the way for growing British influence and consequently changed their policy towards Iran. Conflicts between the state and national movements (such as Gilan and Azerbaijan) and foreign powers such as Russia, Britain, the Ottomans and Germany) hindered one of these powers from acquiring complete supremacy in Iran. But each could dissuade the other from his intentions. Under such circumstances, many Iranians demanded a government powerful enough to create concentration, effective governance, and to implement reforms (Ghani, 2000).

The liberal theorists and modernists of the Constitutional Revolution, who were influenced by liberal democratic ideas and escaped the concentration of power and sought the separation of powers, hoped to advance the project of modernization of the state and the society through the constitutional revolution to the supporters of the 1921 Persian coup d'état in Iran. They demanded the concentration of power to witness the formation of an authoritarian bureaucratic state. They were no longer inter- 
ested in freedom and democracy and wanted to provide security for development and modernity (Behnām, 2000). The clerics also wanted to end the unrest of the time and maintain the sanctity of Islam and Muslims in line with the merchants who also sought to security in order to continue their business (Bahār, 1984). In one of its editorial articles, Kāveh ${ }^{7}$ Magazine criticizes the frequent change of cabinet: "Every rebel and insurgence at every corner of the country lasts as long as the ministry of several cabinets." The rebellion and insurrection have spread throughout the country and it is not possible to subdue these insurgents and ensure the security of the provinces except with army, artillery and force (Kāveh, 1960).

According to the authors, the presence of a wise and capable Iranian leader who recognized the real needs of the nation and knew how to respond to them was absolutely vital at that time. Thus, after a fifteen-years of chaos caused by the Constitutional Revolution, most social forces gathered around the discourse of the Constitutional Revolution, and the nationalist discourse of the bureaucratic authoritarian state sought to absorb the dispersed forces of the constitutional discourse. The new discourse of the authoritarian bureaucratic state (Pahlavi I) attempted to create an authoritarian state to provide security and thus the cycle of tyranny-chaos repeated. Therefore, due to the unstable conditions in the country and the serious divergence in Iran, most people and intellectuals were convinced that a powerful but reformist state like the authoritarian Pahlavi I state being capable of establishing national unity and security would replace the constitutional state. Therefore, national unity and security became the discourse of the intellectuals and political elites of the time.

\section{CONCLUSION}

To sum up, the constitutional movement and discourse did not implement the process of integrating the political and administrative fields. The political power of the central state was lost by the revolt and obstinacy of the Khāns and centrifugal movements in whole parts of the country, including the tribal and nomadic areas. The spread of administrative influence and bureaucracy were never established in all regions of Iran. Besides the lack of integration of the political and administrative spheres to achieve national unity, the development of communication, as the most important tools of national unity, was not the focus of special attention. Another factor behind the collapse of constitutional discourse has been the lack of attention to the expansion of the road network and the development of education in all regions of the country in order to achieve national unity.

Accordingly, and because of the lack of focus on political power and bureaucracy, constitutional discourse could not bring about the dramatic changes in education as it could play a very effective role in creating national solidarity. Economic and social

7 The Persian-speaking exile periodical Kāveh was founded in 1916 by the Intelligence Agency for the Orient (Nachrichtenstelle für den Orient-NfdO) of the Federal Foreign Office in Berlin. It was published twice a month between 1916 and 1922 by Seyyed Hasan Taghizadeh (1878-1970), who also wrote articles for the journal Ayandeh from 1925-1928, and Seyyed Mohammad Ali Jamālzadeh (1892-1997). The title refers to an Iranian mythical hero: Kāveh, a smith from Isfahan. 
modernization, the celebration of the Ferdowsi millennium, the choice of Solar Hijri year as the basis of the official calendar, the use of the name of Iran, the fight against any heterogeneous sign could be continued in the direction of unity and national solidarity. For this reason, the national unity discourse was not formed, but the Pahlavi government used the same national unity discourse to install an authoritarian bureaucratic state. One of the goals and missions of the Constitutional Revolution was to overcome obstacles to nation building in Iran. This mission like another ones ended in failure in constitutional revolution and even after this period the nation-building project encountered with diverse barriers which includes: the powerful presence of tribal and nomadic centers in different parts of the country and their constant clashes with the central government and urban regions, ethno-linguistic, cultural and religious dispersion and finally the absence of a common and national language inside the frontiers of country to promote educational, economic, political and cultural infrastructures. The necessity to find the components of national identity has led intellectuals to highlight important concepts such as government, nation and country.

In this situation, the Persian language, as the most important feature of Iranian nationality has been the focus of attention among nationalist intellectuals which due its precious heritage, could tie the past with the future and continue to offer the possibility of its dynamicity and mobility. The development of nationalist ideas, which later emerged as the theoretical and practical foundations of the Pahlavi's government ideology, was largely under the influence of Kāveh Ayandeh, Irānshahr and Farangistān Magazines writers' thoughts. This prospect, along with the intersecting interests of neighboring governments and foreign powers, the lack of internal trade and economic interactions, the existence of cultural and religious inconsistencies, and the long-term presence of supra-regional powers, have added to the complexity of the political situation around Iran. Such a situation has increased the potential for conflict and reduced Iran's long-term security, and has been a serious obstacle to install the stable nationstate and to deepen the lasting security in the Middle East.

Despite all these changes, Iran still retains the importance of its geographic location. It must maintain this idea and take this special position into account in its foreign policy with neighboring and non-neighboring countries. The balance between foreign forces has always been in the interest of Iran's independence and territorial integrity, and in the current situation, the adoption of a positive neutral policy falls within the scope of the Iranian state. The extreme external threats, the lack of religious or cultural support in the current situation, the long and uncontrollable borders and the internal ethno-linguistic heterogeneity and their external links are four major factors which dominate the space and the strategic environment of Iran and reflect the country's position at the international and regional level. In this research, the authors conclude that the dominance of mutual hostility between Iran and the United States and its impact on increasing foreign threats and its combination with more stable sources of conflict and tension with neighbors, the domination of questionable relations between Iran and Turkey, Iran and Japan, the unresolved problems of Iran-Iraq war, the continuation of territorial and border disputes with its neighbors, terrorism and drug trafficking are major challenges for Iran's national security and a major obstacle to democracy and state-building in Iran. 


\section{REFERENCES}

Adamiyat F. (2008), The Ideology of Iran's Constitutional Movement, Vol. 1, Gostareh.

Ahmadi H. (2011), Ethnicity and ethnocentrism in Iran, Ney.

Andersen N. A. (2003), Discourse Analytical Strategies: Foucault, Koselleck, Laclau, Luhmann, Policy Press.

Bahār M. (1984), A Brief History of Political Parties of Iran, 1st edition, Vol. 1, Amirkabir.

Behnām J. (2000), Iranian Intellectuals in Berlin, 1st edition, Forouzān.

Browne E. G. (1918), The Persian Constitutional movement, British Academy.

Chouliaraki L., Fairclough N. (1999), Discourse in Late Modernity: Rethinking Critical Discourse Analysis, Edinburgh University Press.

Clarke C. Brown A., Hailey V. (2009), Working Identities? Antagonistic Discursive Resources and Managerial Identity, "Human relations", 62 (3): 323-352.

Cottom R. (1992), Nationalism in Iran, Translated into Persian by: Ahmad Taddayon, Kavir.

Cronin S., Cronin D., Cronin S. M. (1997), The Army and Creation of the Pahlavi State in Iran, 1921-26, IB Tauris.

Fiyouzat E. (1996), State in Pahlavi Period, 1st edition, Chapakhsh.

Gellner E. (1983), Nations and Nationalism, Basil Blackwell.

Ghani C., Ghanī S. (2000), Iran and the Rise of Rezā Shāh: From Qājār Collapse to Pahlavi Power, IB Tauris.

Gramsci A., Hoare Q. (1971), Selections from the Prison Notebooks, Lawrence and Wishart.

Hāeri A. (2001), Shi 'ism and Constitution in Iran and the Role of Iranians in Iraq, Amirkabir.

Hāfez Nia M. (2002), Geopolitics of Iran, SAMT.

Howarth D., Stavrakakis Y. (2000), Introducing Discourse Theory and Political Analysis, in: Discourse theory and political analysis: identities, hegemonies and social change, (eds.) D. Howarth, A. Norval, Y. Stavrakakis, Manchester University Press, Manchester-New York: 1-24.

Husseini S. (1994), Some Unknown Hints on Iran's Contemporary History, 1st edition, Navid-e-No, Shirāz.

Husseini Zādeh M. A. (2007), Political Islam in Iran, Mofid University Press.

Karimi Pour Y. (1992), Geo-politic Analysis of Critical Areas in Sistan and Baluchestan. Doctoral dissertation, Tarbiat Modares University.

Karimi Pour Y. (2000), Iran and Neighbors, University Press.

Kasraei M. (2000), The Challenge of Tradition and Modernity, 1st edition, Markaz.

Kasraei M. S., Pouzesh Shirazi A. (2009), Laclau and Mouffe's Discourse Theory as an Effective Tool for Understanding and Explaining Political Phenomenon, "Journal of Politics": 339-360.

Kāveh Magazine (1960): 1.

Laclau E., Mouffe C. (1985), Hegemony and Socialist Strategy: Towards a Radical Democratic Politics, Verso.

Maki H. (2001), Twenty Years of Iran's History, 6th edition, Vol. 3-4, Elmi.

Mirheidar D. (2011), Five Decades of Developments in Thought and Geo-political Issue, Papli.

Mouffe C. (2008), Critique as counter-hegemonic intervention. Transversal multilingual web journal, http://eipcp.net/transversal/0808/mouffe/en/print (20 Jan 2013).

Nāzem H. (1954), Russia and Great Britain in Iran (1900-1914), Columbia University. 
Rahbari M. (2009), Constitutional Revolution: Religious renaissance in Iran, "Research in Political Science", No. 1: 105-134.

Rasoulzādeh M. A. (1998), Reports from Iranian Constitutional Revolution, Translated into Persian by: Rahim Raeis Nia, 1st edition, Shirāzeh.

Rowshanfekr M. (2018), Modernity and Tribal Society of Boyer-Ahmad in Pahlavi Period, 1st edition, Movarekhān.

Sha'bāni R. (2006), Social History of Iran: the Basics, Qomes.

Tabari E. (1978), Iranian Society in Rezā Shāh's Period, Ferdows.

Tājik M. (2008), The Analysis of the Ninth Period of Iran Presidential Election, "Journal of Humanities", No. 61: 75-95.

Torfing J. (1999), New Theories of Discourse, Laclau, Mouffe and Źiźek, Blackwell.

Zibākalām S. (1998), Tradition and Modernity, Rowzaneh.

\begin{abstract}
Throughout the history, the formation of the constitutional state has been the first experience of the modern state in Iran. The change in power relations and the restriction of authoritarian power were among the most important issues of constitutional state. The current study aims at investigating the reasons for transition from Constitutional state to an authoritarian bureaucratic state by adopting Laclau and Mouffe's framework to political discourse analysis. Research methodology is descriptive-analytical conducted by library-based data. The results showed that the constitutional revolution transformed the power structure and traditional state, but the constitutional revolution failed to create a new order. Despite legal provisions such as the formation of the parliamentary system and the constitution, the constitutional state was unable to exercise its legal power. The co-existence of traditional and reactionary components such as the Khānins, tribal leaders, tribal populations and owners in line with modern elements, intellectuals and the heterogeneity of the ruling political elites made the constitutional revolution incapable of producing profound politico-social changes. As a result, a number of internal and external factors such as financial crisis, tribal power, the imperialist treaty of 1907,disillusionment of political elites, the formation of centrifugal forces, insecurity and global chaos and development of neighboring countries, diversity of ideological in line with geopolitical points of view have been the most important factors in the transition to the authoritarian bureaucratic state of Pahlavi and the failure of the nation - building process and the collapse of politicoconstitutional system in Iran.
\end{abstract}

Keywords: nation-building, constitutional state, authoritarian state, discourse analysis, Laclau \& Mouffe

\title{
ZROZUMIENIE POWODÓW PRZEJŚCIA Z IRAŃSKIEGO PAŃSTWA KONSTYTUCYJNEGO DO PAŃSTWA AUTORYTYCZNEGO: ANALIZA W RAMACH TEORII DYSKURSU LACLAU I MOUFFE'A
}

\section{STRESZCZENIE}

Na przestrzeni dziejów tworzenie państwa konstytucyjnego było pierwszym doświadczeniem nowoczesnego państwa w Iranie. Zmiana stosunków władzy i ograniczenie władzy auto- 
rytarnej należało do najważniejszych kwestii państwa konstytucyjnego. Niniejsze badanie ma na celu zbadanie przyczyn przejścia od państwa konstytucyjnego do autorytarnego państwa biurokratycznego poprzez przyjęcie ram Laclau i Mouffe do analizy dyskursu politycznego. Metodologia badań jest opisowo-analityczna, przeprowadzona na podstawie danych bibliotecznych. Wyniki analizy pokazały, że rewolucja konstytucyjna przekształciła strukturę władzy i tradycyjne państwo, ale rewolucja konstytucyjna nie stworzyła nowego porządku. Pomimo przepisów prawnych, takich jak ukształtowanie parlamentu i konstytucja, państwo konstytucyjne nie było w stanie sprawować swojej władzy prawnej. Współistnienie tradycyjnych i reakcyjnych elementów, takich jak Chaninowie, przywódcy plemienni, populacje plemienne i właściciele zgodnie z elementami nowoczesnymi, intelektualiści i heterogeniczność rządzących elit politycznych, sprawiły, że rewolucja konstytucyjna nie była w stanie wywołać głębokich zmian polityczno-społecznych. W efekcie powstało szereg czynników wewnętrznych i zewnętrznych, takich jak kryzys finansowy, władza plemienna, traktat imperialistyczny z 1907 r., rozczarowanie elit politycznych, powstawanie sił odśrodkowych, niepewność i globalny chaos oraz rozwój krajów sąsiednich, różnorodność ideologiczna w zgodzie z geopolitycznym punktem widzenia były najważniejszymi czynnikami w przejściu do autorytarnego, biurokratycznego państwa Pahlawi oraz porażce procesu budowania narodu i upadku systemu polityczno-konstytucyjnego w Iranie.

Slowa kluczowe: budowanie narodu, państwo konstytucyjne, państwo autorytarne, analiza dyskursu, Laclau \& Mouffe 
